\title{
Approach to Topographic Map, Hydrogeological and Environmental Isotopes Analysis to Delineation of Watersheds in Drought-prone Areas
}

Agus Budhie Wijatna ${ }^{1}$ and Tarsisius Aris Sunantyo ${ }^{2}$

${ }^{1}$ Department of Nuclear Engineering and Engineering Physics, Faculty of Engineering, Universitas Gadjah Mada, Yogyakarta, Indonesia ${ }^{2}$ Department of Geodetic, Faculty of Engineering, Universitas Gadjah Mada, Yogyakarta, Indonesia.

1'gusbudiftugm@gmail.com, ${ }^{2}$ sunantyo@ugm.ac.id

\begin{abstract}
Gunung Kidul regency is one of the regencies in Indonesia that almost every year (often) is susceptible to drought, there is an even in term of synonymous with a drought in the province. Water is the essential lifeblood on Earth, with the power to generate, sustain, receive, and ultimately to unify life. Water is also one of the most important resources that need to be protected, conserved, and maintained to support humanity and all life on earth. Drought is a state of shortage of water supply in an area in which a prolonged period (several months to years). Usually, these events appear if a region is continuously subjected to rainfall below the average. Dry season long will cause drought. Drought is also a lack of water for human life and other living things in an area that is usually not a lack of water.
\end{abstract}

The environmental isotopes most widely used as a tracer in the study of hydrology cycle are the stable isotopes deuterium $(2 \mathrm{H})$, oxygen-18 $(18 \mathrm{O})$ and carbon-13 and the radioisotopes tritium $(3 \mathrm{H})$ and carbon-14 $(14 \mathrm{C})$. The use of environmental isotopes as a tracer in groundwater studies are usually complementary to approach topography, hydro geology, and geology which has been frequently used.

The result of this research show that elevation as an orthometric height of the 15 wells water in the research has a variation elevation which spread at most of the district in The from $-18.390 \mathrm{~m}$ at Girisubo district up to 238.599 at Nglipar district $\mathrm{m}$. Concerning with elevation of the water table at several geological cross section (East - West $\backslash$ ) are close to orthometric height.Keywords - Delineation; watersheds; drought-prone; tracer; environmental isotopes.

\section{Introduction}

Gunung Kidul regency is one of the regencies in Indonesia that almost every year (often) is susceptible to drought, there is an even in term of synonymous with a drought in the province [1]. Water is the essential lifeblood on Earth, with the power to generate, sustain, receive, and ultimately to unify life. Water is also one of the most important resources that need to be protected, conserved, and maintained to support humanity and all life on earth. Drought is a state of shortage of water supply in an area in which a prolonged period (several months to years). Usually, these events appear if a region is continuously subjected to rainfall below the average. Dry season long will cause drought. Drought is also a lack of water for human life and other living things in an area that is usually not a lack of water. The regency is part of southern mountains tertiary Rocks [2]. The regency consists of 18 districts and geographical; is located at $110^{\circ} 21$ 'to $110^{\circ} 50^{\prime}$ east longitude and $7^{0} 46^{\prime}$ to $8^{0} 09^{\prime}$ south latitude (see Figure 1). Based on geographic location and the existing ecosystem, the regency generally is an area that often experiences water shortages despite having relatively high rainfall.

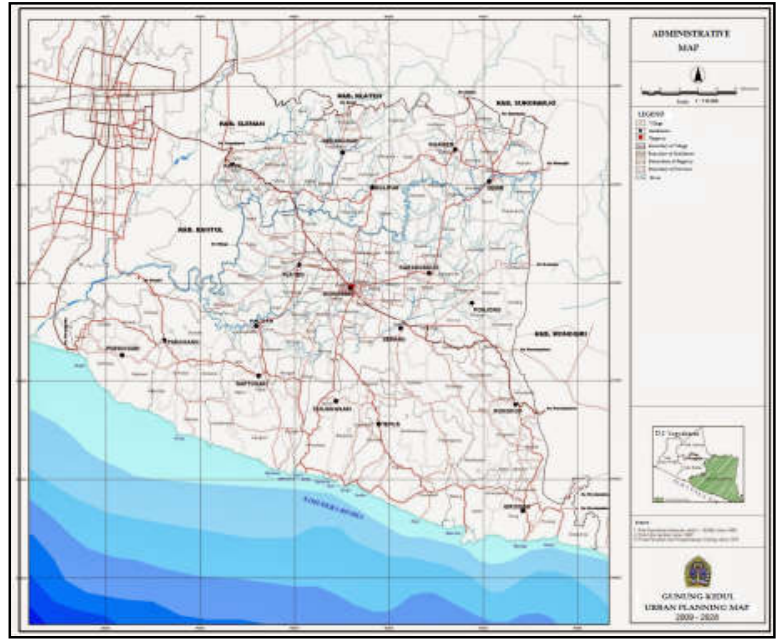

Fig. 1. Administrative maps belong to the regency [3]

All of the districts belong to the regency appears at Fig.1, it also appears that all of the roads which connect among districts. For rural communities, especially in karts mountainous areas, meeting water needs by relying 
on groundwater sources is highly unlikely. Concerning with clean water facilities and infrastructure barriers, the regency is mostly in a hilly area so it requires a big money to carry out investment for infrastructure to service water for community people in all of the district. The government regency has still tried to get too much money for servicing clean water for the community. In the regency, there are many underground rivers, but to take an advantage of the water required huge costs and high technology. Water sources in the regency until today has been exploited by water wells, springs, water from PDAM network, reservoirs or ponds and rainwater collected from a roof into storage tanks. Most subdistricts of the regency nearly years of drought, especially in the dry season. In the rainy season, all of the residents need water from filled springs, wells, water ponds and rainwater. Dug wells with a depth of over 10 meters widely used of the population in the district of the regency. Springs scattered in the district widely used to meet the various needs of life. In the dry season, dug wells, springs, and even some bin-bin rainwater become dry causing drought for citizens.

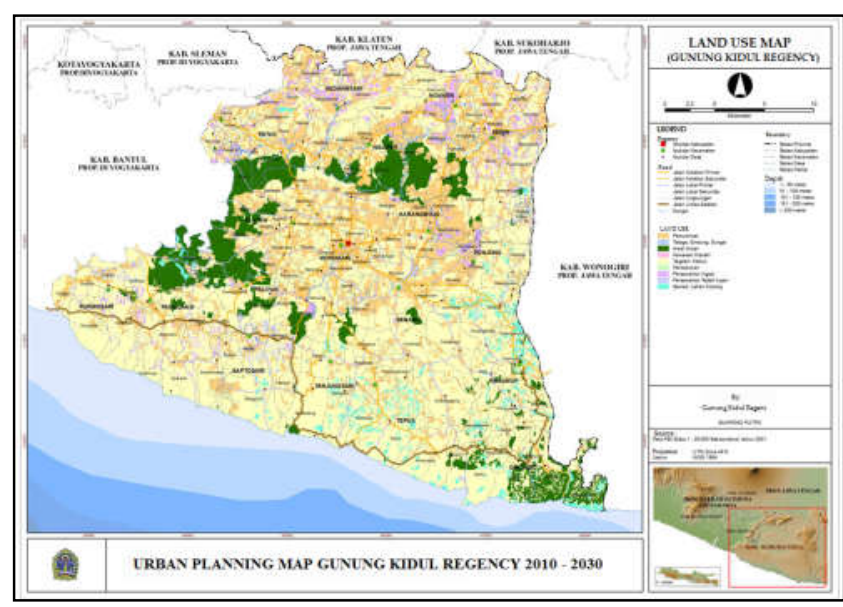

Fig. 2. Land use map belongs in the regency [3]

There is causes droughts such as the thin soil layer; groundwater; texture rough ground; climate; vegetation and topography. The low or high topography of a region affects the soil water content owned. Usually, the lowlying areas will have a soil water content which is more than in the highlands.



Fig. 3. Topographic map in the regency [3]

Due the water is absorbed by the soil which will flow from a high place to low place. Therefore because of the water will be more absorbed by the soil in the lower plains.

The Fig. 3 tells that green color is a forest. It means that coverage area of forest is lesser than other land use. Based on the topography, the regency can be characterized to be three zones above sea level. The zones are a north zone with has an orthometric height between 200 up to $700 \mathrm{~m}$, the central zone between 150 up to $200 \mathrm{~m}$ and the south zone between 0 up to $300 \mathrm{~m}$ [4]. Concerning with Figure 3, a variation of colors at topographic map indicate the elevation of the area, it tells that red color is the highest elevation. Variation of colors at every district is different from place to place. The Variation of colors has changed gradually from red to green colors. It means that green color is the lowest elevation which is close beach as the long beach in the regency. [5] states that the topography determines whether there is an active movement of water through decay material. The role of the topography is as a motion controller groundwater upright (vertical), and it also affects the process of leaching and surface erosion that will determine the rate of removal of the result of weathering.

Delimitation and extensive water catchment areas with the approach of topography, geology, and hydro geology has been done by some researchers, however such an approach cannot be sure whether the water in the springs truly comes from catchment areas are being researched or derived from local rain come from the aquifer around or comes from catchments on it.

\section{Approach/Methodology}

There are several technologies to study watersheds in drought-prone. One of the technologies for the study delineation of watersheds in drought-prone areas is able to be done by using environmental isotopes tracer method. The research area as a case study is in several districts of the regency. In the science of hydrology, basic flow known as base flow or flow mainstay and role important 
as the only component of water supply (discharge) during the dry season.

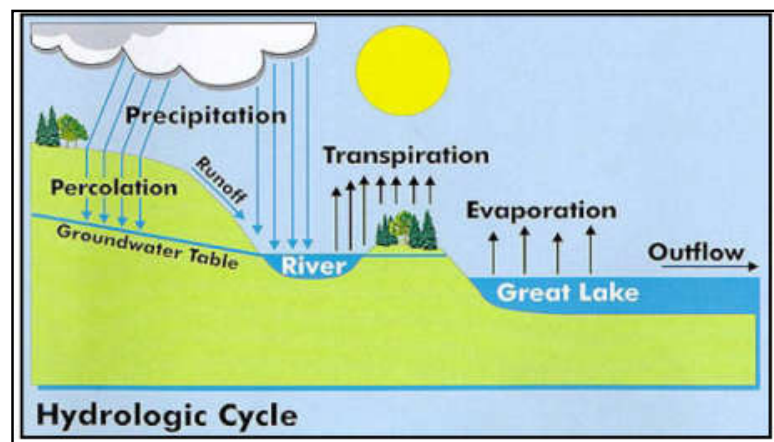

Fig. 4. Water continually recycled and returned to the ecosystem through the hydrology cycle [6]

Concerning with evapotranspiration in the regency as an average during in the year of 2007 is shown in Table1.

Table 1. Evapotranspiration in the regency [3]

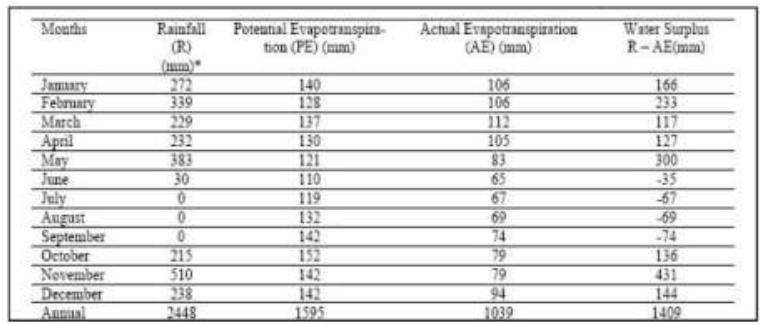

Watershed hydrology (see Fig. 4 and Fig. 5) is a field of study that concerns itself with questions of where the water goes

when it rains, what flow paths the water takes to the stream, and how long water resides in the watershed.

From the Table 1, it tells that rainfall from January up to December is very different and has a big variation. Annual rainfall is $2448 \mathrm{~mm}$ per year. Potential evapotranspiration does not have a big different variation.

Water surplus from January up to December has a big variation between $-74 \mathrm{~mm}$ up to $233 \mathrm{~mm}$ and its water surplus annually is $1409 \mathrm{~mm}$. The average rainfall in the regency in the year 2007 of was $1720.86 \mathrm{~mm} /$ year with the number of rainy days on average 115 days per year. In the wet season of months are 4 up to 6 months, while the dry season of months is from 4 up 5 months. The rainy season begins in October up to November and ends in May-June every year. Rainfall peak season is in December up to February. The north regency is a region which has the highest rainfall over central and southern regions, while southern areas at the end rain. Temperatures of the regency for a daily average temperature is about $27.7{ }^{\circ} \mathrm{C}$, where minimum temperature is about $23.2{ }^{\circ} \mathrm{C}$ and the maximum temperature is about $32.4{ }^{\circ} \mathrm{C}$. Relative humidity in the regency has a range between $80 \%$ up to $85 \%$. The relative humidity in the regency is not too affected by the high places, but it is influenced by season. The highest humidity occurs in the months January to March, while the lowest in September.

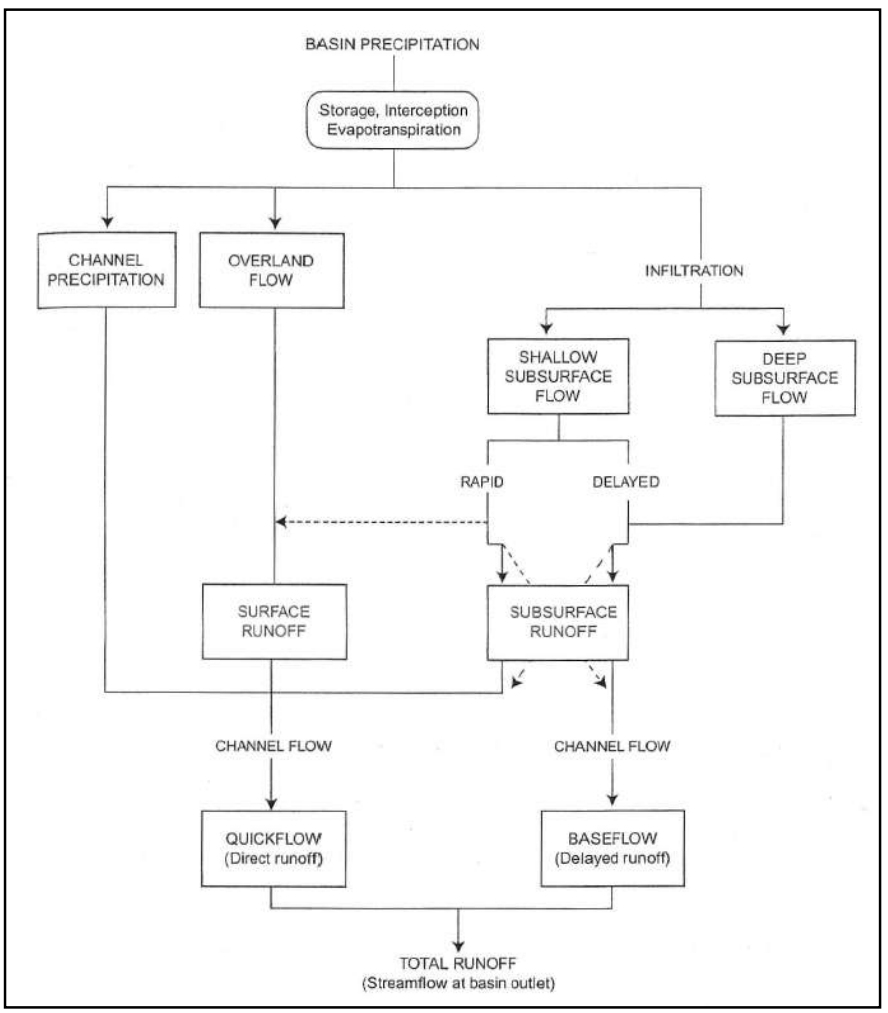

Fig. 5. Presentation of flow paths through a watershed from precipitation to stream flow at the basin outlet [7]

Methodology to carry out research consists of field survey and laboratory experiments. Field survey is aimed to look for the well pump which spread in the regency. Every location of the well pump has been taken data several data such as geodetic position, temperature, deep of good pump and additional explanation about utilities etc. Condition of groundwater in the regency can be seen in Fig.6.

The field survey was carried out about one month (three weeks in March and one week in April 2016) for 15 locations. Survey methods in the field by taking well water by pumping samples are 15 districts (see Figure 2). Names of the 15 district are Playen, Paliyan, Nglipar, Gedangsari, Tanjungsari, Nglipar (two points), Girisubo, Ponjong, Saptosari and Wonosari (four points). At the 15 selected locations as a sample of this research at the 15 districts, raw data were taken such as position (geodetic coordinate system), temperature, sample of water from the well pump and deep of the well pump. 




Fig. 6. Groundwater depth map at The regency between in the year of 2010 up to 2030 [3]

Laboratory experiments have been carried out in several steps. The first step of data processing is to analyze an assessment of watershed hypothesis of delineation using a topographical map. The second of data processing is to carry out to analyze assessment of watershed hypothesis of delineation using a cross section of the geological map of the research area. The last step of laboratory experiments is to analyze the isotopes ratio $\left({ }^{2} \mathrm{H} /{ }^{1} \mathrm{H}\right.$ or $\left.{ }^{18} \mathrm{O} /{ }^{16} \mathrm{O}\right)$ of the water sample which determined by mass spectroscopy at National Nuclear Energy Agency of Indonesia- BATAN Jakarta to get the boundaries of water catchment area. In the laboratory experiments, several analysis was done such as computation for transformation of the 15 points from geodetic coordinates system to be UTM coordinates system and orthometric height system, plotting of the 15 point at topographic map, Orthometric height $(\mathrm{H})$ can be obtained by leveling and gravity observations and it has a physical meaning and depends on the gravity field of the earth. The orthometric height $(\mathrm{H})$ is the length of the plumb line between the station $\mathrm{P}$ and $\mathrm{P}_{0}$ at the geoid. Usually, orthometric height is measured by spirit leveling. $\mathrm{H}$ is also called the "height above Mean Sea Level".

\subsection{Height System}

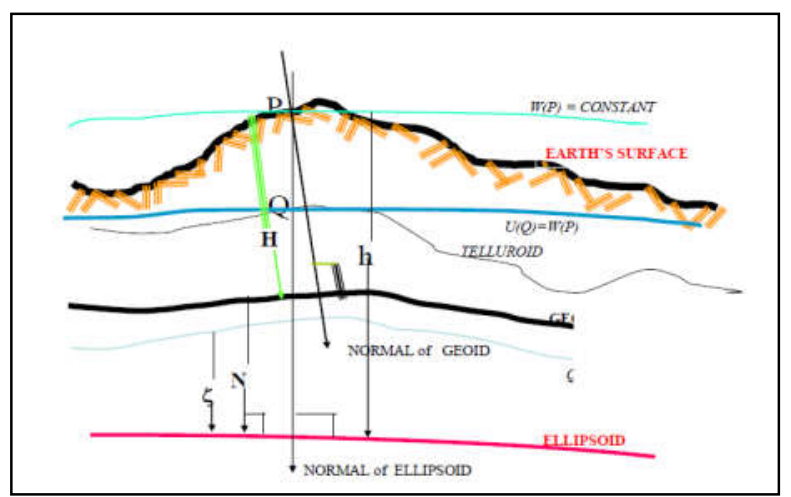

Fig. 7. Height system after modified [8]
Concerning with Fig. 7, it can be seen that geoid undulation $(\mathrm{N})$ is the difference between ellipsoidal height (h) and orthometric height $(\mathrm{H})$. The geoidal undulation $(\mathrm{N})$ is defined as the height of geoid above (positive) or below (negative) the defined reference ellipsoid [8]. Ellipsoidal height (h) is the plumb line from the observation point at the topographical surface to the ellipsoid, and $\mathrm{h}$ is measured using GPS receivers. Ellipsoidal height (h) is a pure geometrical value. The local geoid is prepared by presenting the distribution of in contour form. This is called the (local) geometric geoid or gravimetric geoid. GPS will provide a direct solution if observed at leveling points with orthometric height information provided through connecting to tide gauges with a simple formula:

$$
\mathrm{H}=\mathrm{h}-\mathrm{N}
$$

where $\mathrm{h}$ is the ellipsoidal height from GPS observation, $\mathrm{H}$ is orthometric height as computed from leveling network adjustment from tide gauges, and $\mathrm{N}$ is the geoidal height. Karts hydrology in the basin coalition river surface and subsurface river Bribin to Baron, the regency that output discharge volume of water availability can be known to be used in the management of water resources. The basin coalition consists of sub river basin district surface (non karts) and subsurface sub-watershed (karts). Debit of basin coalition as a continuous function of time is still unknown. The available data are very limited and temporary nature (event), but it is known that the output of perennial water. The basin coalition is a combination not yet well-defined system, given that most limits and extent cannot be ascertained as a result of a complex karts area. Sub-basin coalition aquifer is limestone surface has cracks and fissures, which are not as intensive as it is owned subsurface sub-watershed and not granular rocks. In subsurface sub-watershed not found the river's surface, but the surface of the minor groove formed in the valley between the hills during the rainy season and the water disappeared through cracks, crevices, caves, which have characteristic karts area [9].

\subsection{The Basic Theory Of Environmental Isotopes Tracer Method [10]}

Waters molecules are built of two elements: hydrogen $(\mathrm{H})$ and Oxygen $(\mathrm{O})$, with general formula, is $\mathrm{H} 2 \mathrm{O}$. Hydrogen has two stable isotopes: protium $(1 \mathrm{H})$ with an abundance of $99.985 \%$, deuterium $(2 \mathrm{H})$ with abundance up to approximately $0.015 \%$ and a radioactive isotope of hydrogen-Tritium $(3 \mathrm{H})$. Oxygen also has three stable isotopes: $16 \mathrm{O}$ (common), $17 \mathrm{O}$ (very rare) and $18 \mathrm{O}$ (rare); whereupon just $18 \mathrm{O}$ is of practical relevance. So several types of water molecules are 1H216O-light, most common water molecule, and $1 \mathrm{H} 218 \mathrm{O}$ and $2 \mathrm{H} 1 \mathrm{H} 16 \mathrm{O}-$ heavy, a rare water molecule. Due to chemical and physical processes, the isotope ratios can be changed (isotope effects). The, therefore, ratio of isotopes is not constant. The isotopic composition of water, determined by mass spectroscopy, is expressed in comparison to the isotopic composition of ocean water, called Standard Mean Ocean Water (SMOW). [11] states that the 
isotopic composition of water is expressed in per mil \%o deviations from the SMOW standard. The deviation of deuterium is written $2 \mathrm{H} / 1 \mathrm{H}$ and $18 \mathrm{O} / 16 \mathrm{O}$ for oxygen-18. [12] The isotope composition of ocean water are well mixed and of rather a uniform composition. In the process of evaporation, an isotopic fraction occurs because the light water molecules are more efficiently evaporated than the heavy ones. Thus, water in the clouds isotopic-ally lighter than ocean water. In contrast, in the process of condensation from the cloud, during rain formation, a reversed fraction of isotope occurs because the heavier water molecules condense more easily than the light ones, leaving the cloud residual vapor depleted of $2 \mathrm{H} / 1 \mathrm{H}$ and $18 \mathrm{O} / 16 \mathrm{O}$ values. [13] As results, the vapor in the clouds is enriched in light water molecules than the ocean that supplied the water, with relatively negative $2 \mathrm{H} / 1 \mathrm{H}$ and $18 \mathrm{O} / 16 \mathrm{O}$ values. In contrast, the residual water phase becomes relatively depleted in light water molecules, more positive $2 \mathrm{H} / 1 \mathrm{H}$ and $180 / 16 \mathrm{O}$ values. [14] states that the basic theory of environmental isotopes tracer method essentially bases on these natural water molecules variations.

\subsection{Delineation Of Watershed Using Environmental Isotopes}

The first and most importance question when we want to conserve water catchment area are, where are the boundaries of water catchment area? First, hypothetical catchment area determined by synthesizing topographic, geological, hydro geological and hydro logical data. Then, hypothetical catchment areas were verified by environmental isotopes tracer method. Environmental isotopes tracer method is not to replace the delineation methods that have been used but is a complement to the methods.

\section{Obtained / Expected Results}

After field survey has been carried out and preliminary result concerning with laboratory experiments, finally several results has been achieved such as 1). Elevation (as a geometric height) of the 15 well pump. The 15 well pump are at Playen (geometric height : $237 \mathrm{~m}$ ), Paliyan (geometric height 192m), Nglipar (geometric height $265 \mathrm{~m}$ and $218 \mathrm{~m}$ ), Gedangsari (geometric height $211 \mathrm{~m}$ ), Tanjungsari (geometric height $4 \mathrm{~m}$ ), two points at Girisubo district (geometric height $4 \mathrm{~m}$ and $7 \mathrm{~m}$ ), Ponjong (geometric height $70 \mathrm{~m}$ ), Saptosari (geometric height $54 \mathrm{~m}$ ) and four points in Wonosari district (geometric height respectively are $231 \mathrm{~m}, 200 \mathrm{~m}, 192 \mathrm{~m}$, and $189 \mathrm{~m}$ ). Geodetic coordinates to be plotted on the land use map are shown in Fig.8 and Fig. 9.

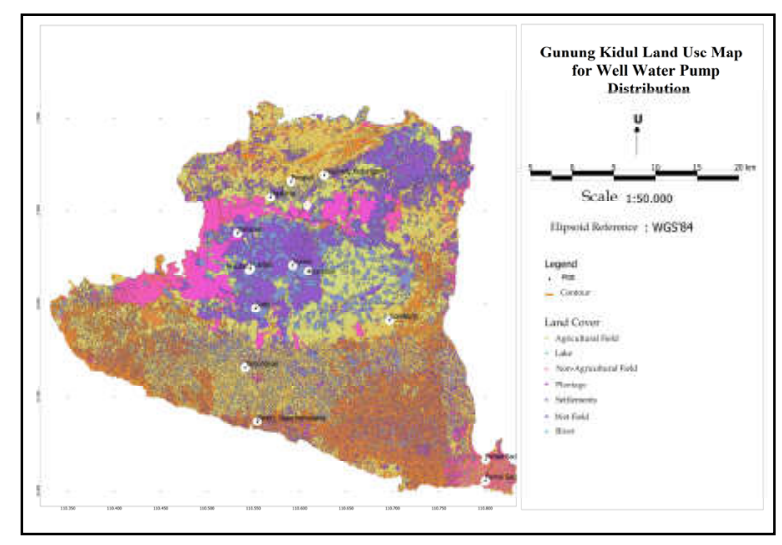

Fig. 7. Height system after modified [8]

2). Geodetic position. GNSS receiver was used to look for positioning such as geodetic coordinates (geodetic latitude, geodetic longitude, and geometric height). The receiver is also used to find positioning with UTM coordinates system for every well pump. 3). Explanation of the well pumps. Distribution using elevation for the 15 well water pump in the regency can be seen in Figure 8. Concerning with the Figure 7, plotting all of well water pump is spreading from north to south direction for the 15 districts. Concerning with orthometric height system, the result area consists of 15 points that have a variation elevation and spread at most of the district in The. 2). Deep water of the 15 well water by pumping are Playen (NA), Paliyan (NA), Nglipar (125m), Gedangsari $(110 \mathrm{~m})$, Tanjungsari $(80 \mathrm{~m})$, two points at Girisubo district (4m and 80m), Ponjong (67m ), Saptosari (70m ) and Wonosari $(40 \mathrm{~m}, 40 \mathrm{~m}, 80 \mathrm{~m}$, and $60 \mathrm{~m}) .4$ ). Based on the function of the 15 well water pump that only 9 well water are in good conditions (it is still used to get water for people). 5). Watershed delineation using a crosssection of the geological map of the research is still in progress and 6). Watershed delineation using tracer hydroisotop over the research is still in progress.

Formula (1) must be used to process orthometric height. Two parameters of carrying out orthometric height are geoid undulation (EGM2008 as a subsurface map) and geometric height (it was obtained by GNSS receiver observation).

The geological cross section is very useful to identify groundwater. Concerning the result of field campaign for every deep well water, those can be used to plot geological cross section. The cross-section of geology describes the distribution of rock laterally and vertically along the geological cross section line. The cross-section of geology was made at any points observed wells and used in the analysis with a trajectory line that passes through the points of the well. 




Fig.9. Contour map for distribution of well water pump in the regency.

Geological cross section was made by using a topographical map that is appropriate scale geological maps. Geological data based Regional Geological Map Sheet Surakarta - Giritontro with a scale of 1: 100,000 made by [15]. Geological data used from the form of data map layers of rock slope, rock types, geological structure and lithology of data distribution. The orthometric height of well pump and groundwater level obtained from field campaign then cross section geology is possible to be made together with groundwater levels sub surface conditions laterally and vertically.

Table 2. Computation Orthometric Height With Respect to the 15 Well Pump

\begin{tabular}{|l|l|l|l|l|}
\hline Village & District & Latitude (D) & Longitude (D) & $\begin{array}{l}\text { Orho. } \\
\text { Height } \\
(\mathrm{m})\end{array}$ \\
\hline Banaran & Playen & -7.923805556 & 110.5330556 & 211.007 \\
\hline Sodo & Paliyan & -8.0045 & 110.5524444 & 166.268 \\
\hline Ngalang & $\begin{array}{l}\text { Gedangsar } \\
\text { i }\end{array}$ & -7.884972222 & 110.5686667 & 184.783 \\
\hline Pengkol & Nglipar & -7.868305556 & 110.5908611 & 191.682 \\
\hline $\begin{array}{l}\text { Mojosari, } \\
\text { Kedungpoh }\end{array}$ & Nglipar & -7.861694444 & 110.6265 & 238.599 \\
\hline $\begin{array}{l}\text { Baron, Desa } \\
\text { Kemadang }\end{array}$ & $\begin{array}{l}\text { Tanjungsa } \\
\text { ri }\end{array}$ & -8.12561111 & 110.5542778 & -21.037 \\
\hline Tanjungsari & $\begin{array}{l}\text { Tanjungsa } \\
\text { ri }\end{array}$ & -8.068527778 & 110.5411667 & -21.396 \\
\hline $\begin{array}{l}\text { Beach of } \\
\text { Sadeng }\end{array}$ & Girisubo & -8.189388889 & 110.8001944 & -21.194 \\
\hline $\begin{array}{l}\text { Beach of } \\
\text { Sadeng }\end{array}$ & Girisubo & -8.167027778 & 110.8003889 & -18.390 \\
\hline Gombang & Ponjong & -8.017888889 & 110.6970556 & 43.909 \\
\hline Ngerenehan & Saptosari & -8.238333333 & 110.5177778 & 30.054 \\
\hline Pulutan & Wonosari & -7.963611111 & 110.5452778 & 163.129 \\
\hline Pulutan & Wonosari & -7.961666667 & 110.5469444 & 166.118 \\
\hline Wonosari & Wonosari & -7.964722222 & 110.60925 & 173.995 \\
\hline Siyono & Wonosari & $-\mathbf{- 7 . 9 5 8 5}$ & 110.5925 & 205.009 \\
\hline
\end{tabular}

The second step of this research is to produce geological cross section. At the beginning plotting of points after field, campaign using geodetic coordinates and deep well water.

Geological map of the regency after the 15 deep well water is shown in Fig. 10.



Fig.10. The geological map at the regency

To have a groundwater map, it is very important to carry out north to south geological cross section. The result of the geological cross section with the north to south direction is shown in Fig. 11.

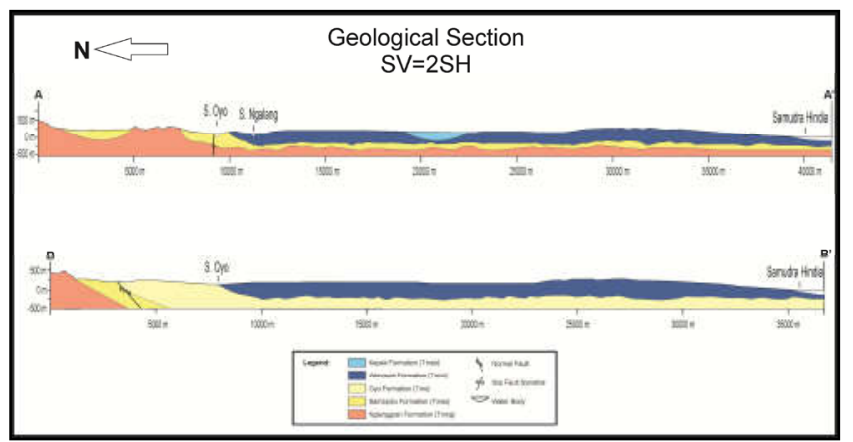

Fig.11. Cross section of Geological map at the researcg using north to south direction

After the geological cross section with north to south direction was done, then a geological cross section with west to east direction was carried out. The result of the geological cross section with west to east direction is shown in Fig. 12. 




Fig.12. Cross section of Geological map at the research using west to east direction

Based on Fig. 10, a geological cross section of every point is very important to know about groundwater of this point, The geological cross section was made eastwest direction and perpendicular with respect to the north-south direction of the regency. The result of every geological cross sections is visualized at Fig. 13.

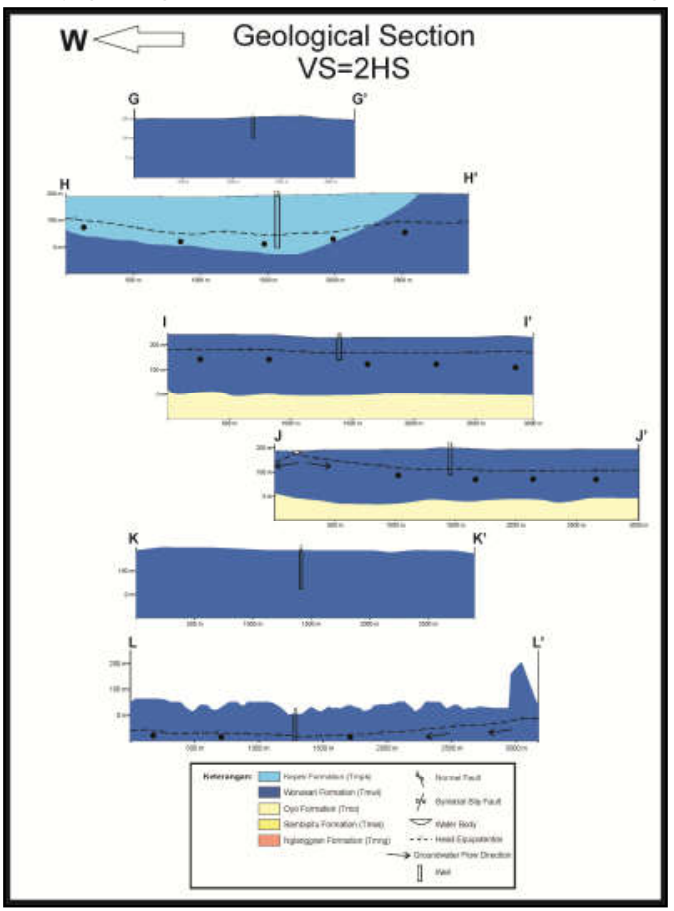

Fig.13. Cross section of Geological map at the research of every cross section perpendicular to the west-east direction

\section{Conclusion}

1. The 15 wells water in the research will be possible to be representative among the 18 districts for all of the districts.

2. Elevation as an orthometric height of the 15 wells water in this research has a variation elevation which spread at most of the district in The from $-18.390 \mathrm{~m}$ at Girisubo district up to 238.599 at Nglipar district $\mathrm{m}$
3. The deep water of the 15 well water pump has a variation from $4 \mathrm{~m}$ up to $125 \mathrm{~m}$.Geological crosssections (north-south direction and east-west direction) very use full to identify delineation of watersheds hypothesis in this regency.

\section{References}

[1] Rusmanto T., Mulyono, dan Irianto B.,2011. Identifikasi gross $\beta$ dan pengukuran parameter air di perairan Wonosari, Prosiding Seminar Penelitian dan Pengelolaan Perangkat Nuklir, Yogyakarta.

[2] Rahardjo, W., 2007. Foraminiferal Biostratigraphy of Southern Mountains Tertiary Rocks, Yogyakarta Special Province. Prosiding "Potensi geolog Pegunungan Selatan dalam Pengembangan Wilayah", Yogyakarta 27-29 November 2007.

[3] Retnowati A., 2014. Culture and Risk Based water and land Management in Karsts Area : An Understanding of Local Knowledge in The Java,Indonesia, Institute fur Geographie Giessen, Germany

[4] Husein, S. dan Sriyono. 2007. Tinjauan Geomorfologi Pegunungan Selatan DIY/Jawa Tengah: Telaah Peran Faktor Endogenik dan Eksogenik dalam Proses Pembentukan Pegunungan. Prosiding Workshop: Potensi geologi Pegunungan Selatan dalam pengembangan wilayah, Hotel Inna Garuda, Yogyakarta, 27- 29 November 2007.

[5] Grim, R.E. 1968. Clay Mineralogy. McGraw-Hill Book Company. New York, St. Louis, San Francisco, Toronto, London, Sydney, 596 p.

[6] Kresic, N. dan Stevanovic, Z., 2010. "Groundwater Hydrology of Springs. Engineering, theory, management, and sustainability". Elsevier Inc., USA. (3):91-104.

[7] Moritz H. and Wellenhof B.H., 2006.Physical geodesy, Springer Wien NewYork,

[8] Soenarto G., 2008. Penaksiran Debit Daerah Pengaliran Gabungan Sungai Permukaan dan Bawah Permukaan Bribin - Baron Kabupaten The Propinsi DIY. ITB., Abstract Dissertation, internet accessed on June 10, 2016.

[9] Kresic N and Stevanovic Z, 2010, Groundwater Hydrology of Springs, Butterworth-Heinemann, USA. pp 91-122 and pp. 312-316.

[10] Mazor Emanuel, 2011, Chemical and Isotopic Groundwater Hydrology, Second Edition, Marcel Dekker Inc., New York-USSA; pp.168-194

[11]Richard W. and Healy, 2010, Estimating Groundwater Recharge, Cambridge University Press, 2010; pp.142-144.

[12] Mazor, Emanuel., 1997. Chemical and Isotopic Groundwater Hydrology. The Applied Approach". Mercel Dekker Ink. 2nd edition. USA. (9):168-194.

[13] MacDonald and Partners.1984. Great Yogyakarta Groundwater study, Directorate General of Water Resources Development of Republic of Indonesia.

[14] Surono, Sudarno and Toha B, 1992, Peta Geologi Lembar Surakarta-Giritontro, Jawa, 1:100.000, Puslitbang Geologi, Bandung. 